\title{
Commentary: Pressure Bandaging for North American Snake Bite? No!
}

\author{
Steven A. Seifert • Julian White • Bart J. Currie
}

Published online: 8 November 2011

(C) This article is being published without copyright 2011

\begin{abstract}
This issue of The Journal of Medical Toxicology includes a position statement regarding the use of pressure immobilization for the pre-hospital treatment of North American Crotalinae envenomation. This commentary discusses the background behind the creation of the position statement and explores the issues involved in applying science to real-world public health recommendations and practice.
\end{abstract}

Keywords Pressure immobilization · Crotalinae .

Envenomation

\section{Commentary}

This issue of The Journal of Medical Toxicology includes a position statement regarding the use of pressure immobilization for the pre-hospital treatment of North American Crotalinae envenomation [1]. It has been jointly

This commentary is being published jointly and simultaneously with Clinical Toxicology and will appear in their December 2011 print issue.

\section{S. A. Seifert $(\bowtie)$}

University of New Mexico Health Sciences Center,

Albuquerque, NM, USA

e-mail: sseifert@salud.unm.edu

\section{J. White}

Toxinology Department, Women's and Children's Hospital,

North Adelaide, SA 5006, Australia

e-mail: julian.white@adelaide.edu.au

\section{B. J. Currie}

Tropical Toxinology Program, Menzies School of Health Research, Charles Darwin University,

Casuarina, NT, Australia

e-mail: bart@menzies.edu.au endorsed by the American College of Medical Toxicology, the American Academy of Clinical Toxicology, the American Association of Poison Control Centers, the International Society on Toxinology, the European Association of Poison Centres and Clinical Toxicologists, and the Asia Pacific Association of Medical Toxicology, and concludes that pressure bandage with immobilization (PBI) cannot be recommended as pre-hospital care in areas such as North America, where non-neurotoxic snakebite is the norm.

This position statement was formulated because of concern about recently published first aid guidelines of the American Heart Association (AHA) and American Red Cross (ARC) [2]. Those guidelines, designed to be applied by bystanders or the victim, included the following:

"Applying [PBI] with a pressure between 40 and $70 \mathrm{~mm} \mathrm{Hg}$ in the upper extremity and between 55 and $70 \mathrm{~mm} \mathrm{Hg}$ in the lower extremity around the entire length of the bitten extremity is an effective and safe way to slow the dissemination of venom by slowing lymph flow (Class IIa, LOE C). For practical purposes pressure is sufficient if the bandage is comfortably tight and snug but allows a finger to be slipped under it. Initially it was theorized that slowing lymphatic flow by external pressure would only benefit victims bitten by snakes producing neurotoxic venom, but the effectiveness of pressure immobilization has also been demonstrated for bites by nonneurotoxic American snakes...."

Even though the AHA/ARC recommendation is weak (Class II: "conditions for which there is conflicting evidence and/or a divergence of opinion about the usefulness/efficacy of a procedure or treatment." Class IIa: 
"weight of evidence/opinion is in favor of usefulness/ efficacy"; level of evidence C: "recommendation based on expert opinion, case studies, or standards of care.") [3] and meant to apply to snakebites worldwide, we are concerned that the recommendations will be applied to North American Crotalinae envenomations. We are also concerned that this guideline was graded above the level of current evidence and that the subtleties of the recommendation grading system are very likely to be underappreciated by most.

The pre-hospital use of PBI in North American snakebite would be a major change in how such cases are managed. The history of snakebite first aid and emergency care is full of concepts that, despite initial theoretical appeal and/or anecdotal evidence, ultimately proved to be harmful. Oncecommon practices, such as tourniquets, cryotherapy, incision, suction, electrotherapy, and fasciotomy, have been eliminated as their effectiveness was refuted, and more importantly, evidence of harm emerged [4-9]. With this perspective, the introduction of a new practice must be based on the scientific demonstration of efficacy and safety.

The application of science to real-world scenarios can be complex. The aim of PBI is to sequester venom in the limb, delaying its arrival into the central circulation and thereby delaying or even preventing the onset of the potential systemic consequences of envenomation [10]. Apart from directly measuring the clinical efficacy of PBI for various endpoints, together with risks of harm of properly applied PBI, it is important to consider context-specific considerations. Key questions are: (1) the certainty regarding the kind of snake involved, (2) the expected time to arrival at a place where definitive therapy can be provided, (3) whether lay individuals are able to distinguish between scenarios with different management considerations, and (4) the likelihood that PBI will be applied correctly or incorrectly and that immobilization can be realistically maintained.

In addition to these concerns, the larger questions include when, how, and on what basis should a new recommendation in the management of snakebite be put forward? Moreover, when universal benefit may not result, should first aid training be guided by utilitarian endpoints in which many patients might benefit by an intervention that harms some, or even worse, harms many patients and benefits few?

When evaluating the application of PBI to Crotalinae envenomations, the science is incomplete. Randomized, prospective, controlled, studies of PBI in human Crotalinae envenomations have not been performed. Our current state of knowledge comes primarily from animal models and a few studies in neurotoxic snakebite, where local tissue injury is not the major concern. This is an entirely different clinical problem to that posed by Crotalinae envenomations, where local tissue injury predominates. Furthermore, extrapolating from animal models to humans can be problematic, especially when animal studies have used fatality from systemic effects - rather than tissue injury — as a primary end-point. The data on tissue injury in animal studies is limited, but a porcine study demonstrated that tissue pressures in a range that would, in other contexts, result in the consideration of fasciotomy, and which might result in ischemic injury, can occur from PBI [11]. Recent studies in humans have demonstrated that both trained and lay individuals applied PBI that resulted in either ineffective or tissue pressures in the same range [12-14]. Finally, the porcine study of Crotalinae envenomation used in support of the AHA/ARC guidelines [2] actually drew the opposite conclusion, stating: "On the basis of our findings, we cannot recommend pressure immobilization widely for viper envenomation..." [11].

Thus the existing science points away from adoption of PBI in Crotalinae envenomation rather than towards it. Given that $98 \%$ of North American venomous snakebites are by Crotalinae, that fewer than $0.2 \%$ of those victims die, and that virtually all have soft-tissue injury, the key question is whether deploying pressure immobilization as a first aid strategy in this context will lead to a large number of people with increased and/or permanent limb injury while saving virtually no lives $[15,16]$. Clearly, more work needs to be done. But our interpretation of the current state of knowledge is that the potential for harm of PBI in the vast majority of Crotalinae envenomations outweighs the potential benefits.

In the context of limited evidence, it is understandable that learned and well-intentioned individuals may disagree. This makes the consensus of toxicologists and envenomation specialists worldwide in opposition to the use of PBI in the prehospital setting all the more striking. The six organizations that endorse the position statement represent the mainstream medical opinion among experts on four continents. There is currently strong consensus that this technique should not be promulgated or taught in areas where non-neurotoxic snakebite predominates. Thus, in North American Crotalinae snakebite, the evidence for PBI would be more properly graded as Class III: "conditions for which there is evidence and/or general agreement that the procedure/treatment is not useful/effective and in some cases may be harmful [3]."

In response to criticisms from members of the clinical toxicology community, the AHA and the ARC have acknowledged that their guideline regarding snakebite does not define the snake groups, geographic locations, and individual circumstances in which PBI might be applicable and also that the data regarding PBI in Crotalinae envenomation are limited and insufficient to deem PBI safe and effective. They are planning to clarify the guideline. For future guidelines, content experts from the position-statement-sponsoring organizations will be invited 
to assist in the writing (Rose Marie Robertson, personal communication 2011). We applaud the AHA and ARC for their evidence-based approach and their ongoing process of review and clarification.

We agree with the conclusions of the position statement: "The use of pressure immobilization for the pre-hospital treatment of North American Crotalinae envenomation is not recommended [1]."

In the absence of definitive data on much of the prehospital management of Crotalinae snakebite, the following recommendations are based on the best available evidence, as well as expert consensus $[17,18]$ :

1. Get a safe distance away from the snake.

2. Remove jewelry and loosen tight-fitting clothing.

3. Loosely splint or otherwise immobilize the extremity in a functional position.

4. As a default action, maintain the bitten extremity in a neutral position with regard to the heart. Other potential actions should be guided by an experienced clinician.

5. Get to a hospital, preferably transported by an EMS provider. In general, supine positioning will prepare providers in managing possible effects such as hypotension and/or vomiting.

6. Avoid useless and/or potentially harmful interventions, such as tourniquets, incision, suction, cryotherapy, or electric shock.

\section{References}

1. American College of Medical Toxicology, American Academy of Clinical Toxicology, American Association of Poison Control Centers, European Association of Poison Control Centres, International Society of Toxinology, Asian Pacific Association of Medical Toxicology (2011) Pressure immobilization after North American Crotalinae snake envenomation. J Med Toxicol. doi:10.1007/s13181-011-0174-2

2. Markenson D, Ferguson JD, Chameides L, Cassan P, Chung K-L, Epstein J, Gonzales L, Herrington RA, Pellegrino JL, Ratcliff N, Singer A (2010) Part 17: first aid: 2010 American Heart Association and American Red Cross Guidelines for First Aid. Circulation 122: S934-S946. doi:10.1161/CIRCULATION.110.971150

3. Tricoci P, Allen JM, Kramer JM, Califf RM, Smith SC Jr (2009) Scientific evidence underlying the ACC/AHA clinical practice guidelines. JAMA 301(8):831-841
4. Cumptson KL (2011) Is there a role for fasciotomy in Crotalinae envenomations in North America? Clin Toxicol 49(5):351-365

5. Alberts MB, Shalit M, LoGalbo F (2004) Suction for venomous snakebite: a study of "mock venom" extraction in a human model. Ann Emerg Med 43(2):181-186

6. Gold BS, Wingert WA (1994) Snake venom poisoning in the United States: a review of therapeutic practice. South Med J 87 (6):579-589

7. Cohen WR, Wetzel W, Kadish A (1992) Local heat and cold application after eastern cottonmouth moccasin (Agkistrodon piscivorus) envenomation in the rat: effect on tissue injury. Toxicon 30(11):1383-1386

8. Corneille MG, Larson S, Stewart RM et al (2006) A large singlecenter experience with treatment of patients with crotalid envenomations: outcomes with and evolution of antivenin therapy. Am J Surg 192(6):848-852

9. Dart RC, Gustafson RA (1991) Failure of electric shock treatment for rattlesnake envenomation. Ann Emerg Med 20 (6):659-661

10. Sutherland SK, Coulter AR, Harris RD (2005) Rationalisation of first-aid measures for elapid snakebite. 1979. Wilderness Environ Med 16(3):164-167

11. Bush SP, Green SM, Laack TA, Hayes WK, Cardwell MD, Tanen DA (2004) Pressure immobilization delays mortality and increases intracompartmental pressure after artificial intramuscular rattlesnake envenomation in a porcine model. Ann Emerg Med 44:599604

12. Canale E, Isbister GK, Currie BJ (2009) Investigating pressure bandaging for snakebite in a simulated setting: bandage type, training and the effect of transport. Emerg Med Australas 21 (3): $184-190$

13. Norris RL, Ngo J, Nolan K, Hooker G (2005) Physicians and lay people are unable to apply pressure immobilization properly in a simulated snakebite scenario. Wilderness Environ Med 16(1):16-21

14. Simpson ID, Tanwar PD, Andrade C, Kochar DK, Norris RL (2008) The Ebbinghaus retention curve: training does not increase the ability to apply pressure immobilisation in simulated snake bite-implications for snake bite first aid in the developing world. Trans R Soc Trop Med Hyg 102(5):451-459

15. Bronstein AC, Spyker DA, Cantilena LR Jr, Green JL, Rumack BH, Giffin SL (2010) 2009 Annual report of the American Association of poison control centers' National Poison Data System (NPDS): 27th annual report. Clin Toxicol 48(10):9791178, http://www.aapcc.org/dnn/Portals/0/correctedannualreport. pdf. Accessed 15 September 2011

16. Seifert SA, Boyer LV, Benson BE, Rogers JJ (2009) AAPCC database characterization of native U.S. venomous snake exposures, 2001-2005. Clin Toxicol (Phila) 47(4):327-335

17. Gold BS, Barish RA, Dart RC (2004) North American snake envenomation: diagnosis, treatment, and management. Emerg Med Clin N Am 22:423-443

18. McKinney PE (2001) Out-of-hospital and interhospital management of crotaline snakebite. Ann Emerg Med 37(2):168-174 